\title{
RESPONSE OF GROWTH AND MINERAL COMPOSITION OF RADISH AND PARSLEY PLANTS TO DIFFERENT N-FORMS, N-LEVELS AND SOME MICRONUTIENTS.
}

Ebed, Fawzia A. A.; G. A. Baddour ${ }^{2}$; Zeinab A. Khidr ${ }^{1}$ and Nora F. G. E. Salem ${ }^{2}$.

1- Botany and Microbiology Dept. Faculty of Science, Al-Azhar Univ.

2- Soil. Water and Environ. Res. Inst.; Agric. Res. Center. Giza. Cairo.

\section{ABSTRACT}

A pot experiment was carried out in the season of 2006 under the green house of El-Mansoura Laboratory for Plant Nutrition, Soil, Water and Environment Institute to study the effect of different $\mathrm{N}$ forms (ammonium nitrate, ammonium sulphate and urea) and doses (30, $45 \& 60 \mathrm{~kg} \mathrm{~N} / \mathrm{fed})$ as well as the effect of foliar application of $\mathrm{Fe}, \mathrm{Mo} \& \mathrm{Mn}$ on growth and mineral composition of radish and parsley plants.

The results revealed that using ammonium nitrate as a source of $\mathrm{N}$ fertilizer recorded the highest value of plant height followed by ammonium sulphate and urea. The height of radish and parsley plants was significantly increased as the level of nitrogen fertilizer increased. The fresh and dry weights were significantly increased up to $60 \mathrm{~kg} \mathrm{~N}$ level. Foliar application of $\mathrm{Fe}, \mathrm{Mn}$ and $\mathrm{Mo}$ as solely or in mixture significantly increased the values of fresh and dry weights compared to the control. Increasing the level of $\mathrm{N}$ fertilizer from 0 to $60 \mathrm{~kg} \mathrm{~N} / \mathrm{fed}$ high significantly increased the concentration of $\mathrm{N}$ and $\mathrm{K}$, while $\mathrm{P}$ concentration was insignificantly affected. Concentration of $\mathrm{N}$ or $\mathrm{K}$ was significantly increased due to micronutrients application, while $\mathrm{P}$ was insignificantly affected. Micronutrients (Fe, Mo and $\mathrm{Mn}$ ) were gradually and significantly increased as the level of $N$ fertilizer was increased up to $45 \mathrm{~kg}$ level of $\mathrm{N}$ fertilization.

Keywords: N-Forms, N-Levels, micronutrients, radish plants, parsley plants.

\section{INTRODUCTION}

Nitrogen is essential for plant growth, it is a constituent of all proteins and nucleic acids, some of the plant growth regulators, many vitamins and hence of all protoplasm. As a component of these and many other compounds, nitrogen is involved in most of the biochemical reactions that compose life. Abd-Allah (2001) studied the effect of heavy nitrogen application on yield and chemical composition of some vegetable plants. He concluded that $\mathrm{NO}_{3}$ will be the only nitrogen source for plants in few days even all the applied nitrogen was $\mathrm{NH}_{4}$ or amide form.

Guo et al. (2007) suggested that ammonium nutrition has a negative effect on plant growth due to the adverse effects of $\mathrm{NH}_{4}$ nutrition on photosynthesis and photorespiration. They also added that, $\mathrm{NO} 3$ and $\mathrm{NH} 4$ nutrition may use different pathways for NADPH consumption, which leads to differences in photosynthesis and photorespiration.

Many investigators studied the effect of nitrogen levels on plant growth of some leafy vegetable plants. They mentioned that fresh weight and total yield of radish, parsley and other plants were increased by increasing the rate of $\mathrm{N}$ fertilizer due to increases in plant height, number of leaves and diameter of the main shoot, (Thapa et al. 2003; Pervez et al. 2004; Chenard et al. 2005 ) 
Talaat (1995) pointed out that increasing the level of $\mathrm{N}$ fertilizer to radish plant resulted in a significant increase in plant height, fresh and dry weights. Such effect might be due to the role of nitrogen in both cell division and cell expansion through its effect on DNA synthesis.

Many investigators indicated that using micronutrients led to an increase in fresh, dry yield and total yield of most leafy vegetables. The increases in plant growth characters due to foliar application of micronutrients may be attributed to the role of these nutrients on plant bioactivities. Molybdenum increased growh, yield and chlorophyll content of some vegetable plants (Kheir, et al. 1991; Kotour, 1998; Chattopadhyay and Mukhopadhyay, 2004). Spraying plants with molybdenum increased nutrient contents, especially N, P, K and Mo (Kotour, 1998; Abd Allah, 2001; ElSawah and Gadallah, 2004; El-Banna and Abd El-Salam, 2005).

Solntera (1976) indicated that Mo enhanced utilization of mineral nutrients from the soil. Iron and manganese increased growth and yield of many plants and also enhanced more accumulation of $\mathrm{N}, \mathrm{P}, \mathrm{K}, \mathrm{Fe}$ and $\mathrm{Mn}(\mathrm{El}$ Shewy, 1981; Talaat, 1995; Abd Allah, 2001 ) .In this respect, Mahmoud and Agwah (1993) reported that spraying lettuce plants with $\mathrm{Fe}$ at $100 \mathrm{ppm}$ significantly increased leaves content of $\mathrm{N}, \mathrm{P}$ and $\mathrm{K}$ as compared with control treatment. Reddy and Malewar (1994) revealed that an addition of Fe (from 0 to $50 \mathrm{ppm}$ ) to soil increased the $\mathrm{P}$ content up to $40 \mathrm{ppm}$. They also found the total Fe content was higher in spinach when grown in soil given 50 ppm Fe.

\section{MATERIALS AND METHODS}

A Pot experiment was carried out during the season of 2006 under the green house of El-Mansoura Laboratory for Plant Nutrition of Soil, Water and Environment Institute; Dakahlya Governorate to estimate the effect of $\mathrm{N}$ fertilization (levels and forms) as well as foliar application of some micronutrients on growth and chemical compositions of radish and parsley plants.

Sixty treatments were arranged in split split block design, which were the simple possible combination between; three forms of $\mathrm{N}$ fertilizers (ammonium nitrate $33.5 \% \mathrm{~N}$, ammonium sulfate $20.5 \% \mathrm{~N}$ and urea $46 \% \mathrm{~N}$ ) were randomly located in the main plot, 4 levels of $\mathrm{N}$ fertilization $(0,30,45$ and $60 \mathrm{~kg} \mathrm{~N} / \mathrm{fed}$ ), were devoted in sub-plot and 5 treatments foliar application of micronutrients were arranged in sub-sub plot as follow:

1- Tap water as a control treatment.

2- Fe-EDTA $(13.5 \% \mathrm{Fe})$ at the rate of $300 \mathrm{ppm}$.

3- Mn-EDTA (13\% Mn) at the rate of $100 \mathrm{ppm}$.

4- Mo as sodium molybdate ( $46 \% \mathrm{Mo})$ at the rate of $50 \mathrm{ppm}$.

5- Mixture of micronutrients (iron, manganese, molybdenum) at the same used rates.

The first addition of $\mathrm{N}$ as well as micronutrients was done after 21 days from sowing date and the second one at 15 days later. For each plant; 180 pots ( $30 \mathrm{~cm}$ in diameter and $40 \mathrm{~cm}$ depth) were used. Each pot was filled with $15 \mathrm{~kg}$ air dry soil taken from the surface layer of a farm near ElMansoura city and analyzed for some physico-chemical properties as shown in Table (1). 
Table 1. Physico-chemical properties of the used soil.

\begin{tabular}{|c|c|c|c|c|c|c|c|}
\hline \multicolumn{8}{|c|}{ Physical analysis } \\
\hline $\begin{array}{c}\text { Coarse } \\
\text { sand } \\
\%\end{array}$ & $\begin{array}{l}\text { Fine } \\
\text { sand } \\
\%\end{array}$ & Silt \% & Clay \% & $\begin{array}{c}\text { Texture } \\
\text { class }\end{array}$ & $\begin{array}{l}\text { Organic } \\
\text { Matter \% }\end{array}$ & $\underset{\%}{\mathrm{CaCO}_{3}}$ & $\begin{array}{l}\text { Saturation } \\
\text { Percentage }\end{array}$ \\
\hline 1.85 & 18.93 & 25.13 & 54.09 & Clayey & 2.13 & 2.85 & 83 \\
\hline \multicolumn{8}{|c|}{ Chemical analysis } \\
\hline \multicolumn{6}{|c|}{ Available nutrients ppm } & $E C^{*}$ & \multirow{2}{*}{$\mathrm{pH}^{\star *}$} \\
\hline $\mathrm{N}$ & $\mathrm{P}$ & $\mathrm{K}$ & $\mathrm{Fe}^{\star \star *}$ & $\mathrm{Mn}^{\star \star \star}$ & $\mathrm{Mo}^{\star \star \star *}$ & $\mathrm{dS} \mathrm{m}^{-1}$ & \\
\hline 68.5 & 5.1 & 425 & 13.5 & 8.3 & 0.73 & 0.37 & 7.6 \\
\hline
\end{tabular}

Twenty seeds for each radish (Raphanus sativus, L.) and parsley (Petroselinum crispum) were sown on 26 and 28 October, respectively. After 20 days from sowing, seedlings were thinned to the most five uniform ones per pot. Soil moisture was kept at $60 \%$ of water holding capacity till the end of the growing season. All other practical cultural processes were carried out as recommended by the Ministry of Agriculture.

At marketing stage; i.e. 55 days from sowing, three plants (foliage) were randomly taken from each pot. Plant height and fresh weight were recorded. Leaf samples were washed 3 times with $0.05 \mathrm{HCl}$ solution followed by washing 3 times with redistilled water to get red of iron, manganese and molybdenum residues, then oven dried at $700 \mathrm{C}$ till constant weight. The dry matter was calculated and expressed as $\mathrm{g} / \mathrm{plant}$ and thoroughly ground for chemical analysis.

Mechanical analysis of the used soil was determined following the international pipette method (Kilmer and Alexander, 1949).

Calcium carbonate, organic matter, available N, P, K, in soil were determined using the methods adopted by Piper (1950); Jackson (1967); Olsen and Sommers (1982) and Black (1965).

The electrical conductivity and soil reaction $(\mathrm{pH})$ were measured according to the method of US Salinity Lab (1954) and Jackson (1967). Iron, manganese and molybdenum in the soil were extracted using DTPA and determined by an Atomic Absorption Spectrophotometer as described by Chapman et al (1961).

The oven dry materials of plant samples were ground and wet digested as described by Peterburgski (1968). The total N, P, K, Fe, Mn and Mo were determined using the techniques described by Pregle (1945) and Chapman et al (1961).

All the obtained data were subjected to statistical analysis according to Gomez and Gomez (1984). Means of treatments were compared using new least significant differences (NLSD) as described by Waller and Duncan (1969).

\section{RESULTS AND DISCUSSION}

\section{Vegetative growth parameters:}

\section{Plant height (cm/plant):}

The statistical analysis of the data presented in Table $2 a$ indicates that height of radish and parsley plants was significantly affected by $\mathrm{N}$ fertilization (forms and levels) as well as foliar application with 
micronutrients. Data also illustrate that the height of both plants was significantly increased by using ammonium nitrate and by increasing of the level of $\mathrm{N}$ fertilization. Foliar application with the mixture of micronutrients studied was superior for increasing the height of radish and parsley plants followed by single application of iron, manganese, molybdenum and finally the control treatment.

With respect to the interactive effect among $\mathrm{N}$ forms, $\mathrm{N}$ levels and foliar application of micronutrients, data indicate that foliar application of iron, manganese and molybdenum as a mixture under the highest level of ammonium nitrate was superior for increasing the height of radish and parsley plants compared to the control treatment. On the other hand, using iron solely was the most effective than the other micronutrients used solely under any level or form of $\mathrm{N}$ fertilization.

Table 2. Effect of different sources and levels of $\mathbf{N}$ fertilization, micronutrients and their interactions on height $(\mathrm{cm})$ of radish and parsley plants.

a) Single effant:

\begin{tabular}{|c|c|c|c|c|c|c|c|c|c|c|c|c|}
\hline \multirow{3}{*}{ Plant } & \multirow{2}{*}{\multicolumn{3}{|c|}{$\overline{\mathrm{X}}(\mathrm{F})$}} & \multirow{2}{*}{\multicolumn{4}{|c|}{$\overline{\mathrm{X}}_{(\mathrm{L})}$}} & \multirow{2}{*}{\multicolumn{5}{|c|}{$\overline{\mathrm{X}}_{(\mathrm{M})}$}} \\
\hline & & & & & & & & & & & & \\
\hline & AN & AS & $U$ & 0 & 30 & 45 & 60 & 0 & $\mathrm{Fe}$ & Mn & Mo & Mix \\
\hline radish & 22.75 & 22.58 & 22.65 & 20.05 & 22.82 & 23.75 & 24.03 & 20.94 & 23.55 & 23.09 & 21.83 & 23.89 \\
\hline parsley & 19.14 & 18.98 & 18.85 & 15.60 & 19.20 & 20.40 & 20.8 & 16.90 & 19.98 & 19.39 & 17.90 & 20.78 \\
\hline
\end{tabular}

b) Interactive effect:

\begin{tabular}{|c|c|c|c|c|c|c|c|c|c|c|c|}
\hline \multicolumn{2}{|c|}{ Treatments } & \multicolumn{10}{|c|}{ Micronutrients (ppm) } \\
\hline \multirow{2}{*}{$\begin{array}{c}\mathrm{N}- \\
\text { forms }\end{array}$} & \multirow{2}{*}{$\begin{array}{l}\text { N levels } \\
\text { (Kg/fed) }\end{array}$} & \multicolumn{2}{|r|}{$\mathbf{0}$} & \multicolumn{2}{|c|}{ Fe } & \multicolumn{2}{|c|}{ Mn } & \multicolumn{2}{|c|}{ Mo } & \multicolumn{2}{|c|}{ Mix } \\
\hline & & radish & parsley & radish & parsley & radish & parsley & radish & barsle & radish & parsley \\
\hline \multirow{4}{*}{ AN } & 0 & 19.4 & 14.9 & 20.3 & 16.2 & 20.0 & 15.6 & 19.6 & 15.1 & 20.7 & 16.8 \\
\hline & 30 & 21.2 & 17.2 & 23.8 & 20.1 & 23.4 & 19.9 & 22.3 & 18.7 & 24.1 & 21.0 \\
\hline & 45 & 21.6 & 17.8 & 25.1 & 21.8 & 24.0 & 21.3 & 22.7 & 18.7 & 25.5 & 22.8 \\
\hline & 60 & 22.0 & 18.4 & 25.2 & 22.5 & 24.8 & 21.5 & 23.0 & 19.2 & 25.7 & 23.3 \\
\hline \multirow{4}{*}{ AS } & 0 & 19.5 & 14.5 & 20.4 & 15.9 & 20.0 & 15.4 & 19.7 & 14.9 & 20.6 & 16.4 \\
\hline & 30 & 20.8 & 17.4 & 23.5 & 19.8 & 23.2 & 19.4 & 22.1 & 18.7 & 24.0 & 20.4 \\
\hline & 45 & 21.3 & 17.6 & 25.0 & 21.8 & 24.2 & 21.0 & 22.4 & 18.8 & 25.3 & 23.0 \\
\hline & 60 & 21.8 & 18.1 & 25.1 & 22.2 & 24.6 & 21.5 & 22.8 & 19.3 & 25.4 & 23.4 \\
\hline \multirow{4}{*}{$\mathbf{U}$} & 0 & 19.5 & 14.5 & 20.4 & 16.3 & 20.1 & 15.6 & 19.7 & 14.8 & 20.8 & 16.6 \\
\hline & 30 & 21.0 & 17.0 & 23.6 & 19.7 & 23.2 & 19.3 & 22.2 & 18.4 & 23.9 & 20.2 \\
\hline & 45 & 21.4 & 17.6 & 25.0 & 21.6 & 24.4 & 20.7 & 22.5 & 18.8 & 25.3 & 22.5 \\
\hline & 60 & 21.8 & 17.8 & 25.2 & 22.0 & 24.7 & 21.4 & 22.9 & 19.3 & 25.4 & 22.8 \\
\hline
\end{tabular}

\begin{tabular}{|c|c|c|c|c|c|c|c|c|c|c|c|c|c|c|c|}
\hline \multicolumn{16}{|c|}{ Statistical Analysis } \\
\hline \multicolumn{2}{|c|}{\begin{tabular}{|l|} 
Treatments \\
\end{tabular}} & \multicolumn{2}{|c|}{$\mathbf{F}$} & \multicolumn{2}{|c|}{$\mathbf{L}$} & \multicolumn{2}{|c|}{$\mathbf{M}$} & \multicolumn{2}{|c|}{ FxL } & \multicolumn{2}{|c|}{ FxM } & \multicolumn{2}{|c|}{ LxM } & \multicolumn{2}{|c|}{ FxLxM } \\
\hline \multirow{2}{*}{\multicolumn{2}{|c|}{ F-test }} & rad. & par. & rad. & par. & rad. & par. & rad. & par. & rad. & par. & rad. & par. & rad. & par. \\
\hline & & ** & ** & $\star \star \star$ & ** & 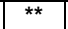 & * & ** & ** & ns & ns & $\star \star \star$ & ** & $\star \star \star$ & * \\
\hline \multirow{2}{*}{ LSD } & $5 \%$ & 0.01 & 0.09 & 0.01 & 0.09 & 0.02 & 0.15 & 0.01 & 0.09 & - & -- & 0.02 & 0.19 & 0.04 & 0.34 \\
\hline & $1 \%$ & 0.02 & 0.16 & 0.02 & 0.12 & 0.03 & 0.21 & 0.02 & 0.11 & -- & -- & 0.03 & 0.26 & 0.05 & 0.45 \\
\hline
\end{tabular}

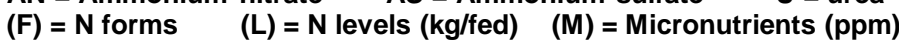

It can be concluded that, the effect of nitrogen fertilization on plant height might be due to the role played by nitrogen in both cell division and cell expansion through its effect on the biosynthesis of some plant hormones. In addition, the increases in the height of radish and parsley plants due to foliar application of micronutrients may be attributed to the role played by these elements on plant bioactivities. These results are on line with those obtained by Bhole et al. (1998), Naguib et al. (2003) and Pervez et al. (2004), working on radish and parsley plants. 


\section{Fresh and dry weights (g/plant):}

Data of Table 3 reveal that there were no significant differences between the mean values either for fresh or dry weight of radish and parsley plants as affected by any form of $\mathrm{N}$ fertilizers used.

However, data indicate that increasing the level of $\mathrm{N}$ fertilization significantly increased the fresh and dry weights of radish and parsley plants. Comparing with the control treatment, the percentages of increase in fresh weight of radish plant were 16.3, 27.4 and $30.2 \%$ and for parsley plant were, $44.2,64.9$ and $71.0 \%$ for the treatments of 30,45 , and $60 \mathrm{~kg} \mathrm{~N} / \mathrm{fed}$, respectively. The same trend was realized for the dry weight of both plants.

It is clear from the data presented in Table $r$ that foliar application of the mixture of micronutrients recorded the highest values of fresh weight followed by iron, manganese, molybdenum and finally the control treatment. The differences between these values were significant. Such effect was realized for the values of dry weight for both plants (Table 4).

Concerning the interactive effect among $\mathrm{N}$ forms, $\mathrm{N}$ levels and micronutrients, results show that foliar application of Fe, Mn, Mo solely or in mixture at any level of $\mathrm{N}$ fertilization had a high significant increase for the values of fresh and dry weights of radish and parsley plants. This trend was realized for any form of $\mathrm{N}$ fertilizers.

It can be concluded that fresh and dry weights of radish and parsley plants were increased by increasing the rate of $\mathrm{N}$ fertilization, this may be due to the beneficial effect of nitrogen on stimulating the merestimatic activity for producing more tissues and organs since nitrogen is a constituent of proteins, nucleic acids and many important substances of plant cell. In this connection, Talaat (1995) reported that the increase in fresh weight of the shoot of radish resulting from increasing $\mathrm{N}$ application is quite expected since it is well established that decreasing the $\mathrm{C} / \mathrm{N}$ ratio within the plant usually favours vegetative growth.

The favourable role of iron, molybdenum and manganese on stimulating vegetative growth of radish and parsley plants may be referred to the role of these nutrients on plant bioactivities through out its effect on enzymatic systems responsible for biosynthesis of amino acids, proteins chlorophyll and through improvement of the nutrient status of the plants, (Chenard et al.,2005 and Mohamed, 2006). In this respect, Mengel and Kirkby (1978) reported that micronutrients are essential elements for plant life, particularly under limiting conditions. They act as plant growth hormones and play an important role in the production and function of several enzyme systems in plants.

\section{Mineral concentration}

\section{Macronutrient concentration ( $\mathrm{N}, \mathrm{P}$ and $\mathrm{K}$ ):}

The statistical analysis of the data presented in Tables 5 to 7 show that the different sources of $\mathrm{N}$ fertilizer had no significant effect on the concentration of N, P and K in radish and parsley plants. Increasing the level of $\mathrm{N}$ fertilization from 0 to $60 \mathrm{~kg} \mathrm{~N} / \mathrm{fed}$ high significantly increased the concentration of $\mathrm{N}$ and $\mathrm{K}$ comparing with control treatment. On the other hand, $\mathrm{P}$ concentration in the leaves of the two plants was not significantly affected by the levels of N fertilization (Table 6).In this respect, Gulser (2005) 
Ebed, Fawzia A. A. et al.

investigated the effects of ammonium sulphate (AS) and urea on nutrient contents in spinach plant. He indicated that increments in nitrogen doses of AS and urea from 0 to $150 \mathrm{~kg} \mathrm{~N} /$ ha significantly increased total $\mathrm{N}$ contents but usually decreased $\mathrm{P}, \mathrm{Zn}$ and $\mathrm{Mn}$ contents. The decrease in micronutrient contents in spinach at the higher nitrogen doses might be due to the dilution effect by increasing the plant biomass.

Table 3. Effect of different sources and levels of $\mathbf{N}$ fertilization, micronutrients and their interaction on fresh weight (g/plant) of radish and parsley plants.

a) Single effert.

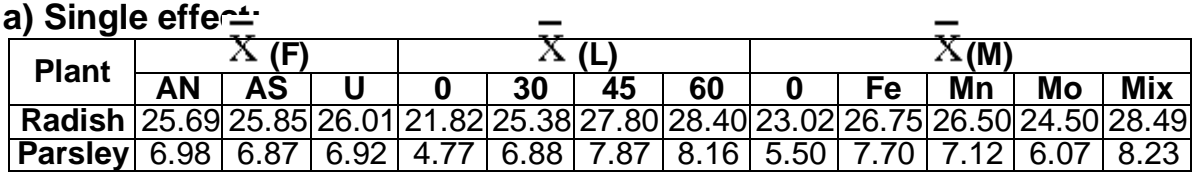

b) Interactive effect:

\begin{tabular}{|c|c|c|c|c|c|c|c|c|c|c|c|}
\hline \multicolumn{2}{|c|}{ Treatments } & \multicolumn{10}{|c|}{ Micronutrients (ppm) } \\
\hline \multirow{2}{*}{$\begin{array}{c}\mathrm{N}- \\
\text { forms }\end{array}$} & \multirow{2}{*}{$\begin{array}{l}\mathrm{N} \text { levels } \\
(\mathrm{Kg} / \mathrm{fed})\end{array}$} & \multicolumn{2}{|r|}{0} & \multicolumn{2}{|r|}{$\mathrm{Fe}$} & \multicolumn{2}{|c|}{ Mn } & \multicolumn{2}{|c|}{ Mo } & \multicolumn{2}{|r|}{ Mix } \\
\hline & & radish & parsley & radisl & \begin{tabular}{|l|l|}
$\mathrm{h}$ & parsley \\
\end{tabular} & radish & parsley & radish & parsley & radish & parsley \\
\hline \multirow{4}{*}{ AN } & 0 & 20.80 & 4.32 & 22.20 & 5.04 & 21.70 & 4.64 & 21.30 & 4.40 & 22.27 & 5.20 \\
\hline & 30 & 22.40 & 60 & 19.22 & 7.52 & 26.70 & 7.36 & 10 & .40 & 28.20 & 7.92 \\
\hline & 45 & 23.99 & 5.92 & 30.03 & 9.36 & 28.70 & 8.16 & 25.80 & 6.64 & 32.03 & 10.00 \\
\hline & 60 & 24.60 & 6.32 & 30.99 & 9.36 & 29.20 & 8.48 & 26.20 & 6.80 & 32.40 & 10.24 \\
\hline \multirow{4}{*}{ AS } & 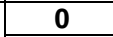 & 20.99 & & & 96 & & 64 & 40 & .40 & 22.80 & 5.20 \\
\hline & 30 & 23.10 & 5.60 & 27.00 & 7.36 & 26 & 7.20 & 24.80 & 6.32 & 27.70 & .68 \\
\hline & 45 & 23.60 & .08 & 29.40 & 8.56 & 28.40 & 8.0 & 25.30 & 6.56 & 31.10 & 9.76 \\
\hline & 60 & 24.20 & 6.08 & 30.30 & 9.36 & 28.80 & 8.56 & 25.99 & 6.80 & 31.60 & 9.92 \\
\hline \multirow{4}{*}{$u$} & 0 & 21.10 & 4.40 & 22.40 & 5.12 & 21.99 & 4.88 & 21.50 & 4.72 & 22.70 & 5.36 \\
\hline & 30 & 23.30 & 5.52 & 27.20 & 7.52 & 26.60 & 6. & 24.93 & 6.32 & 28.00 & 7.92 \\
\hline & 45 & 23.70 & 5.84 & 29.50 & 8.88 & 28.60 & 8.08 & 25.60 & 6.64 & 31.30 & 9.60 \\
\hline & 60 & 24.40 & 6.00 & 30.50 & 9.36 & 29.03 & 8.48 & 26.03 & 6.80 & 31.80 & 9.92 \\
\hline
\end{tabular}

\begin{tabular}{|c|c|c|c|c|c|c|c|c|c|c|c|c|c|c|c|}
\hline \multicolumn{16}{|c|}{ Statistical Analysis } \\
\hline \multirow{2}{*}{\multicolumn{2}{|c|}{ Treatments }} & \multicolumn{2}{|c|}{$\bar{F}$} & \multicolumn{2}{|c|}{ L } & \multicolumn{2}{|c|}{$\mathrm{M}$} & \multicolumn{2}{|c|}{ FxL } & \multicolumn{2}{|c|}{ FxM } & \multicolumn{2}{|c|}{ LxM } & \multicolumn{2}{|c|}{ FXLXM } \\
\hline & & rad. & par. & rad. & par. & rad. & par. & rad. & par. & rad. & par. & rad. & par. & rad. & par. \\
\hline \multicolumn{2}{|c|}{ F-test } & ns & ns & ** & ** & ** & ** & ns & ns & ns & ns & ** & ** & ** & ** \\
\hline \multirow{2}{*}{ LSD } & $5 \%$ & -- & -- & 0.82 & 0.06 & 1.42 & 0.09 & - & - & -- & -- & 1.73 & 0.16 & 2.99 & 0.27 \\
\hline & $1 \%$ & -- & -- & 1.13 & 0.07 & 1.95 & 0.13 & -- & - & -- & -- & 2.28 & 0.21 & 3.96 & 0.36 \\
\hline
\end{tabular}

$\begin{array}{lll}(\mathrm{F})=\mathrm{N} \text { forms } & (\mathrm{L})=\mathrm{N} \text { levels }(\mathrm{kg} / \mathrm{fed}) & (\mathrm{M})=\text { Micronutrients }(\mathrm{ppm})\end{array}$

Table 4. Effect of different sources and levels of $\mathbf{N}$ fertilization, micronutrients and their interaction on dry weight ( $g / p l a n t)$ of radish and parsley plants.

a) Single effect:

\begin{tabular}{|c|c|c|c|c|c|c|c|c|c|c|c|c|}
\hline \multirow{2}{*}{ Plant } & \multicolumn{3}{|c|}{$\overline{\mathrm{X}}_{\mathbf{( F )}}$} & \multicolumn{4}{c|}{$\overline{\mathrm{X}}_{(\mathbf{L})}$} & \multicolumn{5}{c|}{$\overline{\mathrm{X}}_{(\mathbf{M})}$} \\
\cline { 2 - 11 } & $\mathbf{A N}$ & $\mathbf{A S}$ & $\mathbf{U}$ & $\mathbf{0}$ & $\mathbf{3 0}$ & $\mathbf{4 5}$ & $\mathbf{6 0}$ & $\mathbf{0}$ & $\mathbf{F e}$ & $\mathbf{M n}$ & $\mathbf{M o}$ & $\mathbf{M i x}$ \\
\hline radish & 2.15 & 2.12 & 2.13 & 1.82 & 2.14 & 2.27 & 2.31 & 1.92 & 2.24 & 2.17 & 2.02 & 2.32 \\
\hline parsley & 2.13 & 2.01 & 1.98 & 1.53 & 2.09 & 2.24 & 2.31 & 1.64 & 2.23 & 2.07 & 1.85 & 2.43 \\
\hline
\end{tabular}


b) Interactive effect:

\begin{tabular}{|c|c|c|c|c|c|c|c|c|c|c|c|}
\hline \multicolumn{2}{|c|}{ Treatments } & \multicolumn{10}{|c|}{ Micronutrients (ppm) } \\
\hline \multirow{2}{*}{$\begin{array}{c}\mathrm{N}- \\
\text { forms }\end{array}$} & \multirow{2}{*}{$\begin{array}{l}\mathrm{N} \text { levels } \\
(\mathrm{Kg} / \mathrm{fed})\end{array}$} & \multicolumn{2}{|r|}{0} & \multicolumn{2}{|c|}{$\mathrm{Fe}$} & \multicolumn{2}{|c|}{ Mn } & \multicolumn{2}{|c|}{ Mo } & \multicolumn{2}{|c|}{ Mix } \\
\hline & & radish & parsley & radish & parsley & radish & parsley & radish & parsley & radish & parsley \\
\hline \multirow{4}{*}{ AN } & 0 & 1.74 & 1.36 & 1.85 & 1.52 & 1.80 & 1.52 & 1.77 & 1.44 & 1.89 & 1.76 \\
\hline & 30 & 1.96 & 1.76 & 2.24 & 2.40 & 2 & 2. & 2.08 & 2.16 & 2.29 & 2.48 \\
\hline & 45 & 2.0 & 6 & 2.42 & 2.64 & 33 & 2.40 & 12 & 2.08 & 2.59 & 2.96 \\
\hline & 60 & 2.04 & 1.84 & 2.48 & 2.72 & 2.37 & 2.40 & 2.16 & 2.16 & 2.63 & 2.88 \\
\hline \multirow{4}{*}{ AS } & $\mathbf{0}$ & 1.75 & 1.44 & 1.86 & 1.60 & 1.81 & 1.52 & 1.78 & 1.44 & 1.91 & 1.76 \\
\hline & 30 & & & 2.21 & 2.16 & & 2. & 55 & 2. & 2.26 & 2.32 \\
\hline & 45 & 1.97 & 68 & 2.39 & 2.48 & 31 & 2.32 & 09 & 1.84 & 2.50 & 2.72 \\
\hline & 60 & 2.01 & 60 & 2.44 & 2.56 & 34 & 2.32 & 2.13 & 2.00 & 2.54 & 2.72 \\
\hline \multirow{4}{*}{ U } & 0 & 1.75 & 1.44 & 1.87 & 1.52 & 1.83 & 1.52 & 1.79 & 1.36 & 1.92 & 1.76 \\
\hline & 30 & 1.94 & 1.60 & 2.22 & 2.08 & 2.19 & 1.92 & 2.07 & 1.92 & 2.27 & 2.32 \\
\hline & 45 & 1.98 & 1.68 & 2.40 & 2.40 & 2.32 & 2.16 & 2.10 & 1.84 & 2.52 & 2.64 \\
\hline & 60 & 2.02 & 1.76 & 2.45 & 2.64 & 2.35 & 2.40 & 2.14 & 1.92 & 2.56 & 2.80 \\
\hline
\end{tabular}

\begin{tabular}{|c|c|c|c|c|c|c|c|c|c|c|c|c|c|c|c|}
\hline \multicolumn{16}{|c|}{ Statistical Analysis } \\
\hline \multicolumn{2}{|c|}{ Treatments } & \multicolumn{2}{|c|}{$\mathrm{F}$} & \multicolumn{2}{|r|}{ L } & \multicolumn{2}{|c|}{$\mathrm{M}$} & \multicolumn{2}{|c|}{ FXL } & \multicolumn{2}{|c|}{ FxM } & \multicolumn{2}{|c|}{ LXM } & \multicolumn{2}{|c|}{ FXLXM } \\
\hline \multirow{2}{*}{\multicolumn{2}{|c|}{ F-test }} & rad. & par & rad. & Par. & rad. & par. & rad. & par & rad. & par. & rad. & par. & rad. & par. \\
\hline & & ns & ns & ** & ** & ** & ** & ns & ns & ns & ns & ** & ** & ** & ** \\
\hline \multirow{2}{*}{ LSD } & $5 \%$ & -- & -- & 0.01 & 0.07 & 0.01 & 0.01 & -- & - & - & - & 0.01 & 0.01 & 0.02 & 0.02 \\
\hline & $1 \%$ & -- & -- & 0.02 & 0.09 & 0.02 & 0.02 & -- & -- & -- & -- & 0.02 & 0.02 & 0.03 & 0.03 \\
\hline
\end{tabular}
$(F)=N$ forms $(\mathrm{L})=\mathbf{N}$ levels $(\mathrm{kg} / \mathrm{fed})$

$(M)=$ Micronutrients $(\mathrm{ppm})$

Data also record that using foliar application of micronutrients as a mixture was superior for increasing the $\mathrm{N}$ and $\mathrm{K}$ concentrations of radish and parsley plants followed by iron, manganese and molybdenum. The percentages of increase in $\mathrm{N}$ concentration for radish plant were 9.9, 7.5, 3.1 and 12.7 (Table 5) and those of $\mathrm{K}$ concentration were 15.1, 13.0, 5.0 and 18.3 (Table 7) for the treatments of Fe, Mn, Mo and Mix., respectively compared to the control. The same trend was realized for parsley plant. Phosphorus concentration was insignificantly affected for both plants as a result of foliar application with micronutrients either in solely way or as a mixture.

Tables $5 b-7 b$ reveal that the interactive effect among $N$ forms, $N$ levels and foliar application of micronutrients high significantly affected the concentration of $\mathrm{N}$ of parsley as well as $\mathrm{K}$ and $\mathrm{P}$ of both plants. Foliar application of iron, manganese and molybdenum as a mixture at the highest level of ammonium nitrate, was superior for increasing $\mathrm{N}, \mathrm{P}$ and $\mathrm{K}$ concentrations. Using Fe solely as a foliar application was more effective than the other micronutrients used under any level and form of $\mathrm{N}$ fertilization.

From these results, it can be concluded that, the increase in $\mathrm{N}$ concentration by increasing the level of $\mathrm{N}$ fertilization may be due to the role of nitrogen in activating the physiological functions of plant cells and in turn the uptake of these nutrients from the soil solution. The increase in $\mathrm{K}$ concentration with increasing $\mathrm{N}$ level is explained by Tisdale and Nelson (1975) who reported that, "Potassium in soils is taken up by the plant as an ion $\left(\mathrm{K}^{+}\right)$, and is thus important to the uptake of the nitrate $\left(\mathrm{NO}_{3}^{-}\right)$in maintaining ionic balance. The influence of $\mathrm{K}^{+}$on nitrate levels is therefore catalytic. Potassium is essential in protein synthesis". 
Foliar application of $\mathrm{Fe}, \mathrm{Mo}$ and $\mathrm{Mn}$ led to an increase in the activity of nitrate reductase enzymes, consequently more reduction of $\mathrm{NO}_{3}-\mathrm{N}$ and $\mathrm{NO}_{2}-\mathrm{N}$ were happened resulted in producing nitrogenous compounds like protein. The increases in the concentration of $\mathrm{P}$ and $\mathrm{K}$ due to the foliar application of $\mathrm{Fe}, \mathrm{Mn}$ and Mo may be attributed to the stimulating effect of these micronutrients on plant bioactivities which resulted in more accumulation of macronutrients in plant leaves. In this respect, Kheir et al. (1991) reported that application of Mo alone or with Fe tended to increase P and K content over the control treatment. Also, Solntera (1976) indicated that Mo enhanced utilization of mineral nutrients from the soil.

The results are satisfactory consistent with those obtained by $\mathrm{El}-$ Mansi et al. (2004); El-Kassas (2005); Ahmed and Morsy (2005) and ElMahdy (2007).

\section{Micronutrient concentration (Fe, Mo and Mn ppm):}

Data in Tables 8a-1.a indicate that using any form of $\mathrm{N}$ fertilizer had no significant effect on the mean values of $\mathrm{Fe}$, Mo and Mn. Values of these nutrients gradually and significantly increased as the level of $\mathrm{N}$ fertilization was increased up to $45 \mathrm{~kg} \mathrm{~N} / \mathrm{fed}$. Increasing the level of $\mathrm{N}$ up to $60 \mathrm{~kg}$ significantly decreased the values of $\mathrm{Fe}$ (the reduction in parsley was insignificant), Mo and $\mathrm{Mn}$ in the two plants; radish and persley.

Data also show that foliar application of Fe, Mo, Mn solely and their mixture resulted in a significant effect on the concentration of $\mathrm{Fe}$, Mo and $\mathrm{Mn}$ in radish and parsley plants.

Table 5. Effect of different sources and levels of $\mathbf{N}$ fertilization, micronutrients and their interaction on $\mathrm{N} \%$ of radish and parsley plants.

\section{a) Single effect:}

\begin{tabular}{|c|c|c|c|c|c|c|c|c|c|c|c|c|}
\hline \multirow{2}{*}{ Plant } & \multicolumn{3}{|c|}{$\bar{X}_{(F)}$} & \multicolumn{4}{|c|}{$\overline{\mathrm{X}}_{(\mathrm{L})}$} & \multicolumn{5}{|c|}{$\overline{\mathrm{X}}_{(\mathrm{M})}$} \\
\hline & $\overline{\mathrm{AN}}$ & AS & $\bar{U}$ & 0 & 30 & \begin{tabular}{|l|}
1 ) \\
\end{tabular} & 60 & 0 & $\mathrm{Fe}$ & $\mathrm{Mn}$ & Mo & Mix \\
\hline radish & 3.12 & 3.10 & 3.11 & 2.84 & 3.11 & 3.23 & 3.27 & 2.92 & 3.21 & 3.14 & 3.01 & 3.29 \\
\hline parsley & 3.39 & 3.31 & 3.38 & 3.05 & 3.37 & 3.45 & 3.56 & 3.15 & 3.49 & 3.42 & 3.25 & 3.49 \\
\hline
\end{tabular}

\section{b) Interactive effect:}

\begin{tabular}{|c|c|c|c|c|c|c|c|c|c|c|c|}
\hline \multicolumn{2}{|c|}{ Treatments } & \multicolumn{10}{|c|}{ Micronutrients (ppm) } \\
\hline \multirow{2}{*}{$\begin{array}{c}\mathrm{N}- \\
\text { forms }\end{array}$} & \multirow{2}{*}{ 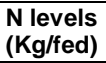 } & \multicolumn{2}{|r|}{$\mathbf{0}$} & \multicolumn{2}{|c|}{$\mathrm{Fe}$} & \multicolumn{2}{|c|}{ Mn } & \multicolumn{2}{|c|}{ Mo } & \multicolumn{2}{|c|}{ Mix } \\
\hline & & radish & parsley & radish & parsley & radish & parsley & radish & parsley & radish & parsley \\
\hline \multirow{4}{*}{ AN } & $\mathbf{0}$ & 2.77 & 2.97 & 2.86 & 3.09 & 2.82 & 3.04 & 2.79 & 2.99 & 2.90 & 3.12 \\
\hline & 30 & 2.95 & 3.18 & 3.21 & 3.49 & 3.17 & 3.45 & 3.05 & 3.30 & 3.25 & 3.54 \\
\hline & 45 & 2.97 & 3.22 & 3.38 & 3.69 & 3.28 & 3.59 & 3.10 & 3.35 & 3.53 & 3.85 \\
\hline & 60 & 3.01 & 3.28 & 3.43 & 3.75 & 3.32 & 3.64 & 3.13 & 3.39 & 3.56 & 3.88 \\
\hline \multirow{4}{*}{ AS } & 0 & 2.78 & 2.99 & 2.88 & 3.09 & 2.83 & 3.05 & 2.80 & 3.01 & 2.92 & 3.13 \\
\hline & 30 & 2.92 & 3.15 & 3.18 & 3.46 & 3.14 & 3.41 & 3.02 & 3.27 & 3.22 & 3.51 \\
\hline & 45 & 2.96 & 3.19 & 3.34 & 3.66 & 3.26 & 3.56 & 3.06 & 3.32 & 3.45 & 2.77 \\
\hline & 60 & 2.98 & 3.23 & 3.39 & 3.71 & 3.30 & 3.61 & 3.12 & 3.37 & 3.49 & 3.80 \\
\hline \multirow{4}{*}{$\mathbf{U}$} & $\mathbf{0}$ & 2.76 & 2.97 & 2.88 & 3.10 & 2.84 & 3.07 & 2.81 & 3.02 & 2.92 & 3.13 \\
\hline & 30 & 2.94 & 3.16 & 3.19 & 3.47 & 3.15 & 3.43 & 3.04 & 3.29 & 3.23 & 3.52 \\
\hline & 45 & 2.97 & 3.20 & 3.36 & 3.68 & 3.28 & 3.57 & 3.08 & 3.33 & 3.47 & 3.79 \\
\hline & 60 & 2.99 & 3.24 & 3.41 & 3.73 & 3.31 & 3.63 & 3.13 & 3.38 & 3.51 & 3.82 \\
\hline
\end{tabular}




\begin{tabular}{|c|c|c|c|c|c|c|c|c|c|c|c|c|c|c|c|}
\hline \multicolumn{16}{|c|}{ Statistical Analysis } \\
\hline \multicolumn{2}{|c|}{ Treatments } & \multicolumn{2}{|c|}{$\mathrm{F}$} & \multicolumn{2}{|r|}{$\mathrm{L}$} & \multicolumn{2}{|c|}{ M } & \multicolumn{2}{|c|}{ FxL } & \multicolumn{2}{|c|}{ FxM } & \multicolumn{2}{|c|}{ LXM } & \multicolumn{2}{|c|}{ FxLxM } \\
\hline \multirow{2}{*}{\multicolumn{2}{|c|}{ F-test }} & rad. & par. & rad. & par. & rad. & par. & ad. & par. & ad. & par & rad. & par. r & rad. & par. \\
\hline & & $\mathrm{ns}$ & $\mathrm{ns}$ & $\star *$ & ** & ** & ** & ns & $\mathrm{ns}$ & $\mathrm{ns}$ & ns & $\star \star *$ & ** & $\mathrm{ns}$ & ** \\
\hline \multirow{2}{*}{ LSD } & $5 \%$ & -- & -- & 0.06 & 0.06 & 0.01 & 0.01 & -- & -- & -- & -- & 0.01 & 0.01 & -- & 0.02 \\
\hline & $1 \%$ & -- & -- & 0.09 & 0.09 & 0.02 & 0.02 & -- & -- & -- & -- & 0.02 & 0.02 & -- & 0.03 \\
\hline
\end{tabular}
$(F)=N$ forms
$(L)=N$ levels $(\mathrm{kg} / \mathrm{fed})$
(M) = Micronutrients (ppm)

Table 6. Effect of different sources and levels of $\mathbf{N}$ fertilization, micronutrients and their interaction on $\mathrm{P} \%$ of radish and parsley plants.

a) Single effect:

\begin{tabular}{|c|c|c|c|c|c|c|c|c|c|c|c|c|}
\hline \multirow{2}{*}{ Plant } & \multicolumn{3}{|c|}{$\bar{X}_{(F)}$} & \multicolumn{4}{|c|}{$\bar{X}_{(L)}$} & \multicolumn{5}{|c|}{$\overline{\mathrm{X}}_{(\mathrm{M})}$} \\
\hline & AN & AS & $\mathbf{U}$ & 0 & 30 & 45 & 60 & 0 & $\mathrm{Fe}$ & Mn & Mo & Mix \\
\hline radish & 0.46 & 0.45 & 0.46 & 0.40 & 0.46 & 0.49 & 0.49 & 0.41 & 0.48 & 0.46 & 0.44 & 0.49 \\
\hline parsley & 0.54 & 0.53 & 0.54 & 0.43 & 0.54 & 0.59 & 0.59 & 0.47 & 0.58 & 0.54 & 0.50 & 0.60 \\
\hline
\end{tabular}

b) Interactive effect:

\begin{tabular}{|c|c|c|c|c|c|c|c|c|c|c|c|}
\hline \multicolumn{2}{|c|}{ Treatments } & \multicolumn{10}{|c|}{ Micronutrients (ppm) } \\
\hline \multirow{2}{*}{\begin{tabular}{|c|}
$\mathrm{N}-$ \\
forms
\end{tabular}} & \multirow{2}{*}{$\begin{array}{l}\mathrm{N} \text { levels } \\
\text { (Kg/fed) }\end{array}$} & \multicolumn{2}{|c|}{0} & \multicolumn{2}{|c|}{$\mathrm{Fe}$} & \multicolumn{2}{|c|}{ Mn } & \multicolumn{2}{|c|}{ Mo } & \multicolumn{2}{|c|}{ Mix } \\
\hline & & radish & parsley & radish & parsley & radish & parsley & radish & parsley & radish & Parsley \\
\hline \multirow{4}{*}{ AN } & 0 & 0.38 & 0.40 & 0.40 & 0.44 & 0.39 & 0.42 & 0.39 & 0.41 & 0.41 & 0.46 \\
\hline & 30 & 0.42 & 0.48 & 0.48 & 0.58 & 0.47 & 0.56 & 0.44 & 0.52 & 0.49 & 0.60 \\
\hline & 45 & 0.43 & 0.49 & 0.51 & 0.65 & 0.49 & 0.61 & 0.45 & 0.54 & 0.54 & 0.69 \\
\hline & 60 & 0.44 & 0.51 & 0.53 & 0.66 & 0.50 & 0.63 & 0.46 & 0.55 & 0.55 & 0.69 \\
\hline \multirow{4}{*}{ AS } & 0 & 0.38 & 0.41 & 0.41 & 0.45 & 0.39 & 0.42 & 0.39 & 0.41 & .41 & 0.46 \\
\hline & 30 & 0.42 & 0.47 & 0.47 & 0.57 & 0.46 & 0.56 & 0.44 & 0.51 & 0.48 & 0.59 \\
\hline & 45 & 0.42 & 0.49 & 0.51 & 0.63 & 0.49 & 0.60 & 0.45 & 0.53 & 0.53 & 0.64 \\
\hline & 60 & 0.43 & 0.50 & 0.52 & 0.65 & 0.50 & 0.47 & 0.46 & 0.54 & 0.54 & 0.67 \\
\hline \multirow{4}{*}{$\mathbf{U}$} & 0 & 0.38 & 0.41 & 0.41 & 0.45 & 0.40 & 0.44 & 0.39 & 0.42 & 0.41 & 0.46 \\
\hline & 30 & 0.42 & 0.48 & 0.47 & 0.58 & 0.47 & 0.56 & 0.44 & 0.52 & 0.48 & 0.59 \\
\hline & 45 & 0.43 & 0.49 & 0.51 & 0.64 & 0.49 & 0.61 & 0.49 & 0.53 & 0.53 & 0.67 \\
\hline & 60 & 0.43 & 0.50 & 0.52 & 0.65 & 0.50 & 0.62 & 0.46 & 0.55 & 0.54 & 0.68 \\
\hline
\end{tabular}

\begin{tabular}{|c|c|c|c|c|c|c|c|c|c|c|c|c|c|c|c|}
\hline \multicolumn{16}{|c|}{ Statistical Analysis } \\
\hline \multicolumn{2}{|c|}{ Treatments } & \multicolumn{2}{|c|}{$\mathrm{F}$} & \multicolumn{2}{|c|}{$L$} & \multicolumn{2}{|c|}{$\mathrm{M}$} & \multicolumn{2}{|c|}{ FxL } & \multicolumn{2}{|c|}{ FxM } & \multicolumn{2}{|c|}{ LxM } & \multicolumn{2}{|c|}{ FxLXM } \\
\hline \multirow{2}{*}{\multicolumn{2}{|c|}{ F-test }} & $\mathrm{rad}$ & par & rad. & par. & rad. & par. & rad. & par & rad. & par. & rad. & par & rad. & par. \\
\hline & & $\mathrm{ns}$ & ns & ns & $\mathrm{ns}$ & $\mathrm{ns}$ & ns & $\mathrm{ns}$ & ns & $\mathrm{ns}$ & ns & ** & ns & ** & ** \\
\hline \multirow{2}{*}{ LSD } & $5 \%$ & -- & -- & -- & -- & -- & -- & -- & -- & -- & -- & 0.002 & -- & 0.01 & 0.06 \\
\hline & $1 \%$ & -- & -- & -- & -- & -- & -- & -- & -- & -- & -- & 0.001 & -- & 0.02 & 0.08 \\
\hline
\end{tabular}

Table 7. Effect of different sources and levels of $\mathbf{N}$ fertilization, micronutrients and their interaction on $\mathrm{K} \%$ of radish and parsley plants.

a) Single effect:

\begin{tabular}{|c|c|c|c|c|c|c|c|c|c|c|c|c|}
\hline \multirow{2}{*}{ Plant } & \multicolumn{3}{|c|}{$\left.\overline{\mathrm{X}}_{\mathbf{~}} \mathbf{F}\right)$} & \multicolumn{4}{c|}{$\overline{\mathrm{X}}_{\mathbf{( L )}}$} & \multicolumn{5}{c|}{$\overline{\mathrm{X}}_{\mathbf{( M )}}$} \\
\cline { 2 - 14 } & $\mathbf{A N}$ & $\mathbf{A S}$ & $\mathbf{U}$ & $\mathbf{0}$ & $\mathbf{3 0}$ & $\mathbf{4 5}$ & $\mathbf{6 0}$ & $\mathbf{0}$ & $\mathbf{F e}$ & $\mathbf{M n}$ & Mo & Mix \\
\hline radish & 3.75 & 3.69 & 3.74 & 3.21 & 3.74 & 3.94 & 4.02 & 3.38 & 3.89 & 3.82 & 3.55 & 4.00 \\
\hline parsley & 4.94 & 4.90 & 4.93 & 4.30 & 4.93 & 5.19 & 5.28 & 4.51 & 5.13 & 4.98 & 4.69 & 5.30 \\
\hline
\end{tabular}


Ebed, Fawzia A. A. et al.

b) Interactive effect:

\begin{tabular}{|c|c|c|c|c|c|c|c|c|c|c|c|}
\hline \multicolumn{2}{|c|}{ Treatments } & \multicolumn{10}{|c|}{ Micronutrients (ppm) } \\
\hline \multirow{2}{*}{\begin{tabular}{|c}
$\mathrm{N}-$ \\
forms
\end{tabular}} & \multirow{2}{*}{$\begin{array}{l}\text { N levels } \\
(\mathrm{Kg} / \mathrm{fed})\end{array}$} & \multicolumn{2}{|r|}{0} & \multicolumn{2}{|c|}{ Fe } & \multicolumn{2}{|c|}{$\mathbf{M n}$} & \multicolumn{2}{|c|}{ Mo } & \multicolumn{2}{|c|}{ Mix } \\
\hline & & radish & parsley & radish & parsley & radish & parsley & radish & parsle & radis! & Parsley \\
\hline \multirow{4}{*}{ AN } & 0 & 3.09 & 4.13 & 3.25 & 4.35 & 3.19 & 4.27 & 3.13 & 4.19 & 3.32 & 4.43 \\
\hline & 30 & 3.43 & 4.59 & 3.93 & 5.13 & 3.85 & 5.05 & 3.64 & 4.80 & 3.99 & 5.21 \\
\hline & 45 & 3.49 & 4.65 & 4.24 & 5.50 & 4.08 & 5.28 & 3.71 & 4.87 & 4.43 & 5.85 \\
\hline & 60 & 3.57 & 4.73 & 4.31 & 5.62 & 4.16 & 5.39 & 3.78 & 4.96 & 4.45 & 5.90 \\
\hline \multirow{4}{*}{ AS } & 0 & 3.10 & 4.15 & 3.28 & 4.39 & 3.20 & 4.30 & 3.14 & 4.22 & 3.35 & 4.46 \\
\hline & 30 & 3.38 & 4.52 & 3.86 & 5.07 & 3.80 & 4.98 & 3.60 & 4.75 & 3.94 & 5.14 \\
\hline & 45 & 3.46 & 4.62 & 3.85 & 5.44 & 4.02 & 5.23 & 3.66 & 4.83 & 4.34 & 5.66 \\
\hline & 60 & 3.51 & 4.67 & 4.26 & 5.54 & 4.33 & 5.32 & 3.74 & 4.90 & 4.06 & 5.75 \\
\hline \multirow{4}{*}{ U } & 0 & 3.08 & 4.16 & 3.30 & 4.41 & 3.23 & 4.32 & 3.16 & 4.25 & 3.37 & 4.50 \\
\hline & 30 & 3.40 & 4.56 & 3.89 & 5.10 & 3.83 & 5.01 & 3.62 & 4.78 & 3.96 & 5.18 \\
\hline & 45 & 3.47 & 4.63 & 4.21 & 5.46 & 4.04 & 5.26 & 3.69 & 4.85 & 4.37 & 5.69 \\
\hline & 60 & 3.54 & 4.69 & 4.29 & 5.58 & 4.13 & 5.35 & 3.77 & 4.92 & 4.41 & 5.80 \\
\hline
\end{tabular}

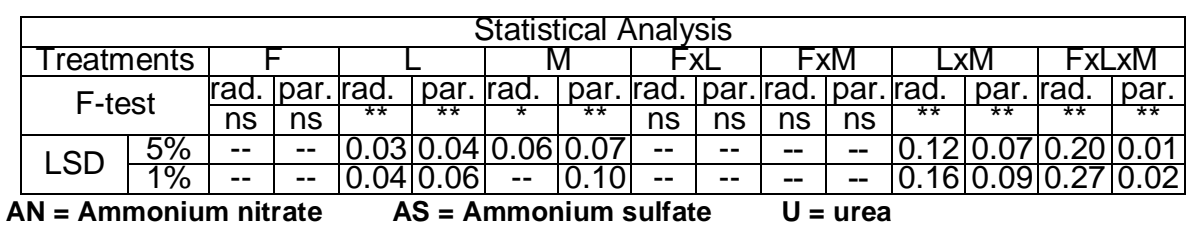
$(F)=N$ forms
$(L)=N$ levels $(\mathrm{kg} / \mathrm{fed})$
(M) = Micronutrients (ppm)

With respect to the interaction among $\mathrm{N}$ forms, $\mathrm{N}$ levels and foliar application of micronutrients, data of Tables $8 b-1 \cdot b$ indicate that the differences between the values for each of $\mathrm{Fe}, \mathrm{Mo}$ and $\mathrm{Mn}$ gradually and significantly increased as the level of $\mathrm{N}$ addition was increased up to the rate of $45 \mathrm{~kg} \mathrm{~N} / \mathrm{fed}$. It can be concluded that, $\mathrm{N}$ fertilization at the higher rates $(60$ $\mathrm{kg} / \mathrm{fed}$ ) resulted in a state of imbalance between nitrogen and micronutrients ( $\mathrm{Fe}, \mathrm{Mo}$ and $\mathrm{Mn}$ ) in the leaves of radish and parsley plants leading to more accumulation of nitrate in the leaves. This can be corrected by foliar spraying of $\mathrm{Fe}, \mathrm{Mo}$ and $\mathrm{Mn}$ which led to an equilibrium between these nutrients within the plant to give an excellent conditions for $\mathrm{NO}_{3}$ reduction and to keep the $\mathrm{NO}_{3}$ accumulation at the lowest value.

Generally, it can be stated that the primitive effects of micronutrients on plant growth and plant chemical composition may be due to their effects on many metabolic and physiological processes and consequently mineral uptake.

The above results are generally in a good agreement with many such finding as those of Abd Allah (2001); El-Sawah and Gadallah (2004) and Kaiser et al. (2005).

Table 8. Effect of different sources and levels of $\mathbf{N}$ fertilization, micronutrients and their interaction on $\mathrm{Fe}(\mathrm{ppm})$ of radish and parsley plants.

a) Single effe

\begin{tabular}{|c|c|c|c|c|c|c|c|c|c|c|c|c|}
\hline \multirow{2}{*}{ Plant } & \multicolumn{3}{|c|}{$\mathrm{X}(\mathrm{F})$} & \multicolumn{4}{|c|}{$\mathrm{X}$ (L) } & \multicolumn{5}{|c|}{$\mathrm{X}(\mathrm{M})$} \\
\hline & AN & AS & $\mathbf{U}$ & 0 & 30 & 45 & 60 & 0 & $\mathrm{Fe}$ & $\mathbf{M n}$ & Mo & Mix \\
\hline radish & 18.3 & 18.7 & 17.9 & 14.0 & 18.3 & 20.9 & 19.9 & 13.7 & 25.7 & 13.3 & 16.9 & 21.7 \\
\hline parsley & 148.1 & 149.6 & 144.0 & 125.8 & 145.3 & 160.5 & 157.2 & 123.1 & 183.9 & 120.6 & 144.4 & 164.0 \\
\hline
\end{tabular}


b)Interactive effect:

\begin{tabular}{|c|c|c|c|c|c|c|c|c|c|c|c|}
\hline \multicolumn{2}{|c|}{ Treatments } & \multicolumn{10}{|c|}{ Micronutrients (ppm) } \\
\hline \multirow{2}{*}{$\begin{array}{c}\mathrm{N}- \\
\text { forms }\end{array}$} & \multirow{2}{*}{$\begin{array}{l}\mathrm{N} \text { levels } \\
\text { (Kg/fed) }\end{array}$} & \multicolumn{2}{|r|}{0} & \multicolumn{2}{|c|}{$\mathrm{Fe}$} & \multicolumn{2}{|c|}{ Mn } & \multicolumn{2}{|c|}{ Mo } & \multicolumn{2}{|c|}{ Mix } \\
\hline & & radish & parsley & radish & parsley & radish & parsley & radish & parsley & radish & Parsley \\
\hline \multirow{4}{*}{ AN } & 0 & 9.74 & 98.00 & 21.42 & 168.00 & 10.64 & 107.00 & 11.41 & 111.00 & 17.39 & 146.00 \\
\hline & 30 & 12.44 & 116.00 & 25.62 & 185.00 & 13.32 & 120.00 & 18.09 & 151.00 & 22.39 & 173.00 \\
\hline & 45 & 16.69 & 141.00 & 29.59 & 194.00 & 14.95 & 130.00 & 18.79 & 155.00 & 24.09 & 180.00 \\
\hline & 60 & 15.72 & 135.00 & 26.49 & 190.00 & 14.24 & 125.00 & 19.41 & 160.00 & 23.14 & 176.00 \\
\hline \multirow{4}{*}{ AS } & 0 & 10.14 & 101.00 & 20.84 & 166.00 & 10.91 & 108.00 & 11.67 & 112.00 & 17.71 & 147.00 \\
\hline & 30 & 12.79 & 117.00 & 26.11 & 187.00 & 13.61 & 122.00 & 18.24 & 153.00 & 22.04 & 172.00 \\
\hline & 45 & 16.99 & 142.00 & 30.74 & 198.00 & 15.19 & 133.00 & 19.09 & 158.00 & 24.81 & 182.00 \\
\hline & 60 & 15.96 & 137.00 & 28.09 & 192.00 & 14.84 & 127.00 & 19.65 & 161.00 & 23.69 & 177.00 \\
\hline \multirow{4}{*}{$\mathbf{U}$} & 0 & 9.84 & 102.00 & 19.72 & 163.00 & 10.49 & 105.00 & 11.14 & 109.00 & 17.11 & 144.00 \\
\hline & 30 & 12.09 & 114.00 & 25.15 & 183.00 & 13.17 & 119.00 & 17.94 & 150.00 & 21.65 & 118.00 \\
\hline & 45 & 16.34 & 140.00 & 28.71 & 193.00 & 14.72 & 128.00 & 18.51 & 154.00 & 23.94 & 179.00 \\
\hline & 60 & 15.39 & 134.00 & 26.32 & 188.00 & 13.93 & 123.00 & 19.19 & 159.00 & 22.89 & 174.00 \\
\hline
\end{tabular}

\begin{tabular}{|c|c|c|c|c|c|c|c|c|c|c|c|c|c|c|c|}
\hline \multicolumn{16}{|c|}{ Statistical Analysis } \\
\hline \multirow{2}{*}{\multicolumn{2}{|c|}{$\begin{array}{c}\text { Treatments } \\
\text { F-test }\end{array}$}} & \multicolumn{2}{|c|}{$\mathrm{F}$} & \multirow{2}{*}{$\begin{array}{r}\mathrm{L} \\
\mathrm{rad} . \mathrm{k}\end{array}$} & \multirow{2}{*}{ par. } & \multicolumn{2}{|c|}{$\mathrm{M}$} & \multicolumn{2}{|c|}{$\begin{array}{c}\text { FxL } \\
\text { rad }\end{array}$} & \multicolumn{2}{|c|}{ FxM } & \multicolumn{2}{|c|}{ LXM } & \multicolumn{2}{|c|}{ FXLXM } \\
\hline & & rad & par. & & & rad. & par. & rad. & par. & rad. & par. & rad. & par. & rad. & par. \\
\hline & & $\mathrm{ns}$ & $\mathrm{ns}$ & ** & ** & ** & ** & ** & ** & ** & ** & ** & & ** & \\
\hline LSL & 0 & - & -- & 0.10 & 5.05 & 0.18 & 8.75 & 0.11 & 5.32 & 0.19 & 9.22 & 0.22 & 10.64 & 0.38 & 18.43 \\
\hline & $1 \%$ & - & - & 0.14 & 6.92 & 0.25 & 11.98 & 0.15 & 7.03 & 0.25 & 12.18 & 0.29 & 14.07 & 0.50 & 24.36 \\
\hline
\end{tabular}
AN = Ammonium nitrate AS = Ammonium sulfate $\mathbf{U}=$ urea
$(F)=N$ forms
(L) = N levels $(\mathrm{kg} / \mathrm{fed})$
$(\mathrm{M})=$ Micronutrients $(\mathrm{ppm})$

Table 9. Effect of different sources and levels of $\mathbf{N}$ fertilization, micronutrients and their interaction on Mo (ppm) of radish and parsley plants.

a) Single effe:t:

\begin{tabular}{|c|c|c|c|c|c|c|c|c|c|c|c|c|}
\hline \multirow{2}{*}{\multicolumn{4}{|c|}{ Single effe $\frac{a \pm:}{X}$}} & \multirow{2}{*}{\multicolumn{4}{|c|}{$\mathrm{X}$ (L) }} & \multirow{2}{*}{\multicolumn{5}{|c|}{$\bar{X}$}} \\
\hline & & & & & & & & & & & & \\
\hline Plan & AN & AS & $\mathbf{U}$ & 0 & 30 & 45 & 60 & 0 & $\mathrm{Fe}$ & Mn & Mo & Mix \\
\hline $\mathrm{rac}$ & 1.04 & 0.99 & 0.99 & 0.62 & 1.04 & 1.24 & 1.12 & 0.58 & 0.93 & 0.54 & 1.60 & 1.38 \\
\hline parsley & 1.33 & 1.32 & 1.28 & 0.88 & 1.31 & 1.56 & 1.48 & 0.85 & 1.18 & 0.79 & 2.07 & 1.66 \\
\hline
\end{tabular}

b) Interactive effect:

\begin{tabular}{|c|c|c|c|c|c|c|c|c|c|c|c|}
\hline \multicolumn{2}{|c|}{ Treatments } & \multicolumn{10}{|c|}{ Micronutrients (ppm) } \\
\hline \multirow{2}{*}{$\begin{array}{c}\mathrm{N}- \\
\text { forms }\end{array}$} & \multirow{2}{*}{$\begin{array}{l}\mathrm{N} \text { levels } \\
\text { (Kg/fed) }\end{array}$} & \multicolumn{2}{|r|}{0} & \multicolumn{2}{|c|}{$\mathbf{F e}$} & \multicolumn{2}{|c|}{ Mn } & \multicolumn{2}{|c|}{ Mo } & \multicolumn{2}{|c|}{ Mix } \\
\hline & & radish & parsley & radish & parsley & radish & parsley & radish & parsley & radish & parsley \\
\hline \multirow{4}{*}{ AN } & 0 & 0.18 & 0.44 & 0.37 & 0.66 & 0.26 & 0.53 & 1.37 & 1.56 & 1.02 & 1.28 \\
\hline & 30 & 0.44 & 0.71 & 1.07 & 1.32 & 0.54 & 0.80 & 1.73 & 2.13 & 1.44 & 1.71 \\
\hline & 45 & 0.88 & 1.17 & 1.16 & 1.39 & 0.72 & 0.96 & 1.91 & 2.40 & 1.58 & 1.95 \\
\hline & 60 & 0.79 & 1.07 & 1.22 & 1.46 & 0.65 & 0.88 & 1.86 & 2.30 & 1.54 & 1.82 \\
\hline \multirow{4}{*}{ AS } & 0 & 0.21 & 0.46 & 0.34 & 0.63 & 0.28 & 0.55 & 1.34 & 1.57 & 0.98 & 1.25 \\
\hline & 30 & 0.47 & 0.74 & 1.06 & 1.29 & 0.55 & 0.82 & 1.68 & 2.08 & 1.59 & 1.67 \\
\hline & 45 & 0.91 & 1.18 & 1.14 & 1.35 & 0.74 & 0.98 & 1.96 & 2.46 & 1.56 & 1.97 \\
\hline & 60 & 0.83 & 1.10 & 1.20 & 1.44 & 0.67 & 0.90 & 0.81 & 2.22 & 1.51 & 1.78 \\
\hline \multirow{4}{*}{$\mathbf{U}$} & 0 & 0.20 & 0.47 & 0.32 & 0.60 & 0.24 & 0.51 & 1.25 & 1.50 & 0.97 & 1.22 \\
\hline & 30 & 0.40 & 0.69 & 1.04 & 1.27 & 0.52 & 0.76 & 1.64 & 2.04 & 1.39 & 1.64 \\
\hline & 45 & 0.86 & 1.14 & 1.10 & 1.34 & 0.69 & 0.94 & 1.88 & 2.35 & 1.55 & 1.87 \\
\hline & 60 & 0.77 & 1.04 & 1.17 & 1.41 & 0.61 & 0.85 & 1.77 & 2.18 & 1.47 & 1.75 \\
\hline
\end{tabular}

\begin{tabular}{|c|c|c|c|c|c|c|c|c|c|c|c|c|c|c|c|}
\hline \multicolumn{16}{|c|}{ Statistical Analysis } \\
\hline \multicolumn{2}{|c|}{ Treatments } & \multicolumn{2}{|c|}{$\mathrm{F}$} & \multicolumn{2}{|r|}{$\mathrm{L}$} & \multicolumn{2}{|c|}{$\mathrm{M}$} & \multicolumn{2}{|c|}{ FxL } & \multicolumn{2}{|c|}{ FxM } & \multicolumn{2}{|c|}{ LxM } & \multicolumn{2}{|c|}{ FxLXM } \\
\hline \multirow{2}{*}{\multicolumn{2}{|c|}{ F-test }} & rad. & par. & rad. & par. & rad. & par. & rad. & par. & rad. & par. & rad. & par. & rad. & par. \\
\hline & & ns & ns & ** & ** & ** & ** & ** & ** & ** & ** & ** & ** & ** & ** \\
\hline \multirow{2}{*}{ LSD } & $5 \%$ & -- & -- & 0.01 & 0.03 & 0.08 & 0.05 & 0.05 & 0.03 & 0.08 & 0.05 & 0.10 & 0.06 & 0.17 & 0.01 \\
\hline & $1 \%$ & -- & -- & 0.02 & 0.04 & 0.11 & 0.06 & 0.06 & 0.04 & 0.11 & 0.06 & 0.13 & 0.07 & 0.22 & 0.02 \\
\hline
\end{tabular}
(F) = N forms
$(L)=N$ levels $(\mathrm{kg} / \mathrm{fed})$
(M) = Micronutrients (ppm) 
Table 10. Effect of different sources and levels of $\mathbf{N}$ fertilization, micronutrients and their interaction on $\mathrm{Mn}(\mathrm{ppm})$ of radish and parsley plants.

a) Single effect:

\begin{tabular}{|c|c|c|c|c|c|c|c|c|c|c|c|c|}
\hline \multirow{2}{*}{ Plant } & \multicolumn{3}{|c|}{$\overline{\mathrm{X}}_{(\mathrm{F})}$} & \multicolumn{4}{|c|}{$\overline{\mathrm{X}}_{(\mathrm{L})}$} & \multicolumn{5}{|c|}{$\overline{\mathrm{X}}_{(\mathrm{M})}$} \\
\hline & AN & AS & $\mathbf{U}$ & 0 & 30 & 45 & 60 & 0 & $\mathrm{Fe}$ & $\mathrm{Mn}$ & Mo & Mix \\
\hline & 3.84 & 3.8 & 3.80 & 3.57 & 3.73 & 4.12 & 3.95 & 2.33 & 3.03 & 5.55 & 3.78 & 4.5 \\
\hline oarsl & 8.60 & 8.60 & 8.47 & 7.87 & 8.31 & 9.11 & 8.95 & 4.75 & 6.58 & 2.52 & 8.44 & 105 \\
\hline
\end{tabular}

b) Interactive effect:

\begin{tabular}{|c|c|c|c|c|c|c|c|c|c|c|c|}
\hline \multicolumn{2}{|c|}{ Treatments } & \multicolumn{10}{|c|}{ Micronutrients (ppm) } \\
\hline \multirow{2}{*}{$\begin{array}{c}\mathrm{N}- \\
\text { forms }\end{array}$} & \multirow{2}{*}{$\begin{array}{l}\text { N levels } \\
(\mathrm{Kg} / \mathrm{fed})\end{array}$} & \multicolumn{2}{|r|}{0} & \multicolumn{2}{|c|}{$\mathrm{Fe}$} & \multicolumn{2}{|c|}{ Mn } & \multicolumn{2}{|c|}{ Mo } & \multicolumn{2}{|c|}{ Mix } \\
\hline & & radish & parsley & radish & parsley & radish & parsley & radish & parsley & radish & parsley \\
\hline \multirow{4}{*}{ AN } & 0 & 2.12 & 4.24 & 2.78 & 5.84 & 5.04 & 11.52 & 3.60 & 7.91 & 4.30 & 9.80 \\
\hline & 30 & 2.24 & 4.55 & 2.97 & 6.34 & 5.34 & 12.23 & 3.71 & 8.17 & 4.57 & 10.31 \\
\hline & 45 & 2.41 & 4.91 & 3.15 & 6.83 & 6.11 & 13.40 & 4.15 & 9.32 & 4.94 & 11.40 \\
\hline & 60 & 2.59 & 5.28 & 3.40 & 7.40 & 5.64 & 12.84 & 3.95 & 8.80 & 3.79 & 10.85 \\
\hline \multirow{4}{*}{ AS } & 0 & 2.09 & 4.28 & 2.71 & 5.62 & 5.19 & 11.81 & 3.52 & 7.78 & 4.38 & 9.94 \\
\hline & 30 & 2.30 & 4.68 & 3.03 & 6.50 & 5.41 & 12.43 & 3.65 & 8.08 & 4.51 & 10.20 \\
\hline & 45 & 2.35 & 4.75 & 3.09 & 6.71 & 6.21 & 13.64 & 4.07 & 9.18 & 4.88 & 11.38 \\
\hline & 60 & 2.65 & 5.39 & 3.33 & 7.45 & 5.84 & 12.92 & 3.89 & 8.61 & 4.71 & 10.74 \\
\hline \multirow{4}{*}{$\mathbf{U}$} & 0 & 2.08 & 4.29 & 2.84 & 5.97 & 5.12 & 11.69 & 3.47 & 7.62 & 4.22 & 9.69 \\
\hline & 30 & 2.18 & 4.41 & 2.90 & 6.19 & 5.25 & 12.04 & 3.46 & 8.34 & 4.45 & 10.11 \\
\hline & 45 & 2.47 & 5.04 & 3.21 & 6.92 & 5.95 & 13.09 & 4.01 & 8.95 & 4.87 & 11.09 \\
\hline & 60 & 2.52 & 5.17 & 2.92 & 7.14 & 5.52 & 12.67 & 3.84 & 8.48 & 4.65 & 10.50 \\
\hline
\end{tabular}

\begin{tabular}{|c|c|c|c|c|c|c|c|c|c|c|c|c|c|c|c|}
\hline \multicolumn{16}{|c|}{ Statistical Analysis } \\
\hline \multicolumn{2}{|c|}{ Treatments } & \multicolumn{2}{|c|}{$\mathrm{F}$} & \multicolumn{2}{|c|}{$\mathrm{L}$} & \multicolumn{2}{|c|}{$\mathrm{M}$} & \multicolumn{2}{|c|}{ FxL } & \multicolumn{2}{|c|}{ FxM } & \multicolumn{2}{|c|}{ LxM } & \multicolumn{2}{|c|}{ FxLxM } \\
\hline \multirow{2}{*}{\multicolumn{2}{|c|}{ F-test }} & rad. & par. & rad. & par. & rad. & par. & rad. & par. & rad. & par. & rad. & par & rad. & par. \\
\hline & & ns & ns & ** & ** & ** & ** & ** & ** & ** & ** & ** & ** & ** & ** \\
\hline \multirow{2}{*}{ LSD } & $5 \%$ & -- & -- & 0.03 & 0.03 & 0.07 & 0.06 & 0.04 & 0.03 & 0.08 & 0.06 & 0.09 & 0.06 & 0.17 & 0.11 \\
\hline & $1 \%$ & -- & -- & 0.05 & 0.05 & 0.09 & 0.08 & 0.06 & 0.04 & 0.11 & 0.08 & 0.13 & 0.08 & 0.23 & 0.15 \\
\hline
\end{tabular}

AN = Ammonium nitrate AS = Ammonium sulfate $\mathrm{U}=$ urea

$\begin{array}{lll}(F)=N \text { forms } & (\mathrm{L})=\mathrm{N} \text { levels }(\mathrm{kg} / \mathrm{fed}) & (\mathrm{M})=\text { Micronutrients }(\mathrm{ppm})\end{array}$

\section{REFERENCES}

Abd Allah, G. E. A. (2001). Effect of heavy nitrogen application on yield and chemical composition of some vegetable crops. Ph.D. Thesis Fac. Agric. Mansoura Univ., Egypt.

Ahmed, A. M. and Morsy, M. A. (2005). The effect of different nitrogen fertilizer sources on nitrate accumulation in tomato plants. Egypt $\mathrm{J}$. App. Sci. 20 (8B): 497-512.

Bhole, M.S.; Gonge, V. S.; Warade, A. D. and Pauthankar, D. H. (1998). Effect of plant density and nitrogen levels on growth and seed yield in radish (Raphanus sativus L.). Advances in Plant Sci., 17 (1): 179-182.

Black, C. A. (1965). Methods of Soil Analysis. Part 2. Amer. Soci. of Agric. [NC] Publisher, Madison, Wisconsin.

Chapman, H. D.; Paker, F. and Pratt (1961). " Methods of Analysis for soils ,plants and waters " Part 2 A. S. S. Madison Wisconsin. 
Chattopadhyay, S.B. and Mukhopadhyay, T.P. (2004). Responose of boron and molybdenum as foliar feeding on onion in tarai soil of west Bengal . Env. Ecology. 22 (1-4): 784-787.

Chenard, C. H.; Kopsell, D. A. and Kopsell, D. E. (2005). Nitrogen concentration affects nutrient and carotenoid accumulation in parsley. J. of Plant Nut., 28 (2): 285-297.

El-Banna, E. N. and Abdel-Salam, H. Z. (2005). Response of potato plants for different sources of potassium with different foliar rates of boron and molybdenum. J. Agric. Sci. Mansoura Univ. 30 (10): 6221-6233.

El-Kassas, A. I. (2005). Response of some sweet pepper hybrids to nitrogen and potassium fertilizer rates under low plastic tunnels in north Sinai. J. Agric. Sci. Mansoura Univ., 30 (8): 4709-4728.

El-Mahdy, R. (2007). Effect of heavy nitrogen application on pepper plant (Capsicum annuum). M. Sc. Thesis Fac. Agric., Mansoura Univ.

El-Mansi, A.A. ; Arisha, H. M.E.; Gomaa, A.Y.M. and Naggar-Soad, A.M. (2004). Effect of organic and mineral nitrogen fertilizers and soil plastic mulch on dry weight, NPK uptake and yield of tomato under sandy soil condition. Zagazig J. Agric. Res. 31(4A): 1301-1319.

El-Shewy, A. A. (1981). Effect of foliar spray with some nutrients and some growth regulators on lettuce plant (Lactuca sativa L.) M.Sc. Thesis Fac. Of Agric Moshtohor, Zagazig Univ.

Gomez, K. A. and Gomez, A. A. (1984). Statistical Procedures for Agricultural Research 2nd ed. John Willey and sons Pub. PP. 139-153.

Gulser, F. (2005). Effect of ammonium sulphate and urea on NO3- and NO2accumulation, nutrient contents and yield criteria in spinach. ScientiaHorticulturae. 106 (3): 330-340.

Guo, S. W.; Xu, Y. Y.; Li, G.Y. and Shen, Q. R. (2007). Nitrogen form affect on photosynthesis and photorespiration. Pedosphere, 17, (5): 601-610.

Jackson, M. L. (1967). "Soil Chemical Analysis Advanced Course" Puble. By the auther, Dept. of soils, Univ. of Wise., Madison 6, Wishensin, U.S.A.

Kaiser, B. N.; Gridley, K. L.; Brady, J. N.; Phillips, T. and Tyerman, S. D. (2005). The role of molybdenum in agricultural plant production. Ann. Botany. 96 (5): 745-754.

Kheir, N. F.; Hanafy, A. A. H.; Abou El-Hassan, E. A. and Harb, E. M. Z. (1991). Physiological studies on the hazardous nitrate accumulation in some vegetables. Bull. Cac., of Agric. Univ., Cairo, 42 (2): 557-576.

Kilmer, V. J. and Alexander, L. T. (1949) Method of making mechanical analysis of soil. Soil Sci. 68: 15-24.

Kotour, S.C. (1998). Synergistic interaction of lime, boron and molybdenum on crud rat and crud yield of cauliflower on an alfisol. Indian J. of Agric. Sci. 68 (5): 268-270. (C.F. Hort. Abs. 68: 10).

Mahmoud, H. A. F., and Agwah, E. M. R. (1993). Response of lettuce plants grown in calcareous soil to plant spacing and $\mathrm{N}$ fertilizer level. Egypt. J. Appl. Sci., 8 (7): 222-236.

Mengel, K. and Kirkby, E. A. (1978). Iron, manganese, zinc and copper. In: Principles of Plant Nutrition, Mengle, K. and E. A. Kirkby (eds), international Postash Institute, 425-474. 
Mohamed, E. M. R. (2006). Study of soil fertility under polluted factors. M. Sc. Thesis. Fac. Agric. Mansoura Univ.

Naguib, N. Y.; Khalil, M. Y. and Abou Zeid, E. N. (2003). Response of some radish cultivars to fertilization with zinc and various nitrogen sources. Bull. National Res. Center, Cairo, 28 (3): 315-336.

Nevein-El-Sawah, A. and Gadallah, F. M. (2004). Response of spinach (Spinacia oleraceal) grown under different forms and rates of $\mathrm{N}$ fertilizer to foliar-feeding with Mo and Mn. 2- chemical constituents and nitrate accumulation. Egypt J. Appl. Sci. 19 (8): 95-118.

Olsen, S. R. and Sommers, L. E. (1982) Phosphorus. P. 103-130. in Page, A. L. et al. (eds) Methods of Soil Analyssi. Part2: Chemical and Microbiological properties. Am. Soc. of Agron., Inc. Madison, Wis, USA.

Pervez, M. A.; Ayub, C. M.; Saleem, B. A.; Virk, N. A. and Nasir, M. (2004). Effect of nitrogen levels and spacing on growth and yield of radish (Raphanus sativus L.). Inter. J. Agric. and Biol., 6 (3): 504-506.

Peterburgski, A. V. (1968). Hand Book of Agronomic Chemistry. Kolas Publishing House, Moscow, (IN Russian, PP. 29-86).

Piper, C. S. (1950). Soil and Plant Analysis. Inter Science Publishers Inc. New York.

Pregle, E. (1945). "Quantitative Organic Micro-analysis" 4th Ed. J. Chudrial, London.

Reddy, N.S. and Moleware, V.G. (1994). Bio available of iron from spinach cultivated in soil fortified with graded levels of iron. Plant food for Human Nutrition 42(4): 313-318.

Solntera N. K. (1976). The effect of molybdenum on nitrogen nutrition of lettuce and radish-shornik Nauchnykh Trudov Belorusski S. Kh. Akademi No. (7): 23-29 (C. F. Hort. Abstr., 47: 5502).

Talaat, B. N. (1995). Physiological studies on reducing the occumidation of nitrate in some vegetable plants. M. Sc. Thesis Fac. Agric. Cairo Univ.

Thapa, U.; Mohanto, B.; Chattopadhyay, S. B. and Ghanti, P. (2003). Growth and yield of some cultivars of radish (Raphanus sativus) with nitrogen levels. Environ. and Ecol., 21 (4): 836-838.

Tisdal, S. L. and Nelson, W. L. (1975). Element Require In Plant Nutrition. In: Soil Fertility and Fertilizers. Mac Millon Publishing Co. Inc. New York.

U.S. Salinity Laboratory Staff (1954). Diagnosis and Improvement of Saline and Alkali Soils. USDA Agric. Hand Book No. 60, Washington, D.C.

Waller, R. A. and Duncan, D. B. (1969). Abays rule for symmetric multiple cimposition problem, Amer. State. Assoc. J., 1485-1503. 
استجابه النمو والتركيب الكيميائى لتباتى الفجل والبقدونس لصور ومعدلات مختلفه

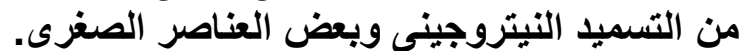

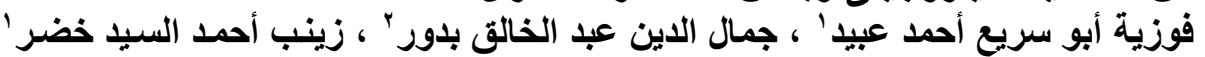

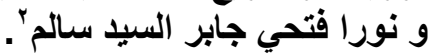

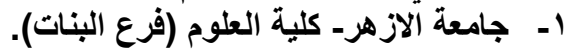
r - معهز بحوث الأراضي والمياه والبيئة مركز البنات البحوث الزراعيةـ الجيزة. القاهرة.

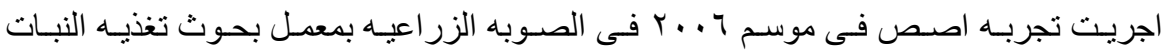

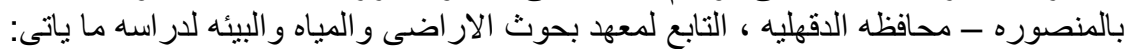

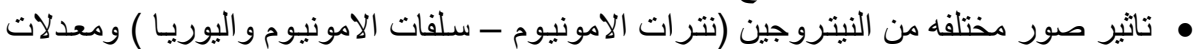

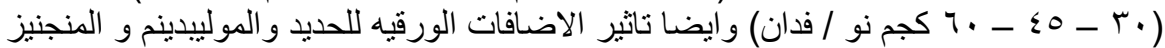

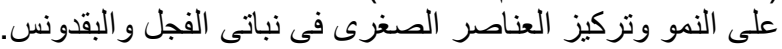

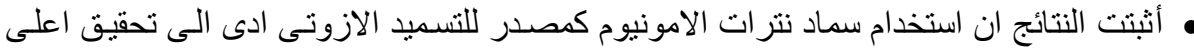

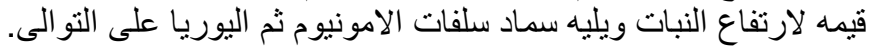

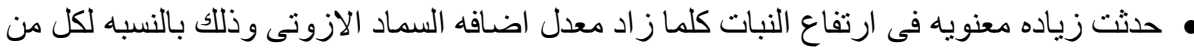
الفجل و البقدونس.

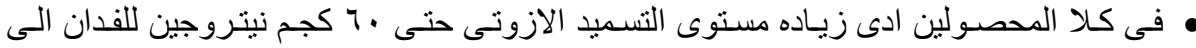

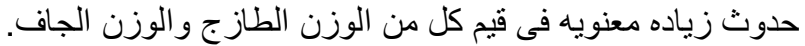

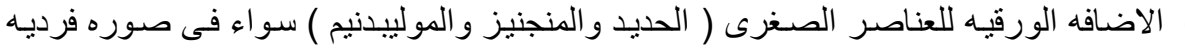

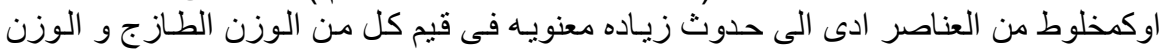

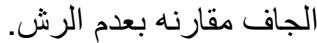

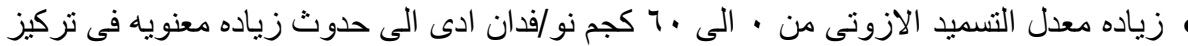

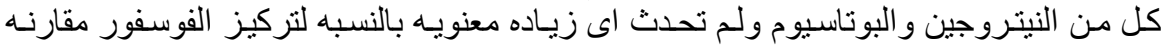

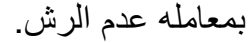

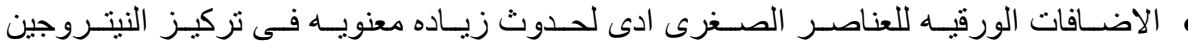

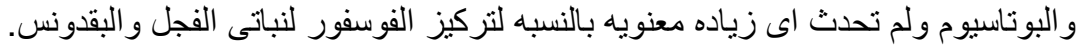

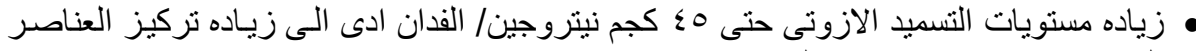
الصغرى (حديد ومنجنيز وموليبدنيم). 

J. Agric. Sci. Mansoura Univ., 34 (4): 4065 - 4079, 2009 